\title{
Structure of Al-Mg-Si Cast and Extruded Rods for Die Forgings
}

Jan Luštinec ${ }^{1}$, Vladivoj Očenášek ${ }^{1}$, Miroslav Jelínek jr. ${ }^{2}$

${ }^{1}$ SVÚM a.s. Tovární 2053, 25088 Čelákovice. Czech Republic. E-mail: lustinec@svum.cz, ocenasek@svum.cz ${ }^{2}$ Strojmetal Aluminium Forging, s.r.o. Ringhofferova 66, 25168 Kamenice. Czech Republic. E-mail: jelinekm@ strojmetal.cz

The manufacture of die forgings from Al-Mg-Si type alloys is one of important topics of material and forming technology development. One of innovation factors affecting the forging technology is based on the use of continually cast rods instead of extruded ones. This change of technology is, however, connected with some problems concerning the structure, an inhomogeneous surface layer, surface morphology of cast rods and increased flow stress of the cast structure as well. The present paper deals with some aspects relating to the inhomogeneity of structure, intermetallic phases and thermomechanical treatment. The investigation of the cast and extruded structure was carried out with the help of optical and electron microscopy.

Keywords: aluminium alloy, casting, extrusion, forging, car industry

\section{Acknowledgement}

The results of the present work were obtained in the framework of TA ČR research project No. TA 02011137 , Production technology development of EN AW 6082 aluminium forgings for chassis parts under variable thermal and forming conditions".

\section{References}

[1] TEMPUS, G., CALLES, W., SCHORF, G. (1991). Influence of extrusion process parameters and texture on mechanical properties of Al-Li extrusions. In: Mat. Sci. and Techn., Vol 7, Issue 10, pp. 937 - 946.

[2] CHOI, S. H., BARLAT, F., LIU, J. (2000). Effect of precipitates on plastic anisotropy of polycrystalline aluminum alloys. In: Materials Science Forum, Vol 331, pp. 1327 - 1332.

[3] SOLAS, D., CANOVA, G., BRECHET, Y., SAINFORT, P. (1996). Anisotropy of mechanical properties in 7010 aluminium thick plates. In: Materials Science Forum, Vol 217 - 222, Issue PART 3 pp. 1533 - 1538.

[4] Van GEERTRUYDEN, W.H. (2004). The origin of surface recrystallization in extrusion of 6xxx aluminium alloys. In: Dissertation Abstract International, Vol. 65-03, Section B, pp. 1503.

[5] OČENÁŠEK, V., CIESLAR, M. (2003). Fatigue inhomogeneity and anisotropy of age-hardenable Al-alloys extrusions. In: Kovové materiály, Vol 41, Issue 5, pp. 313 - 324.

[6] KOVALČÍK, T., STOULIL, J., SLÁMA, P., VOJTĚCH, D. (2015). The influence of heat treatment on mechanical and corrosion properties of wrought aluminium alloys 2024 and 6064. In: Manufacturing Technology, Vol. 15, Issue 1, pp. $54-61$.

[7] PRŮŠA, F., VOJTĚCH, D., BERNATIKOVÁ, A., DVORSKÝ, D. (2015). Mechanical alloying: A way how to improve properties of aluminium alloys. In: Manufacturing Technology, Vol. 15, Issue 6, pp. 1036 - 1043.

[8] OČENÁŠEK, V. (2015). Forging development of the aluminium alloys for the car industry. In: Kovárenství, Vol. 53 , pp. $56-59$.

[9] OČENÁŠEK, V., SEDLÁČEK, P., JELÍNEK, M. (2007). Homogenisation impact on structure and properties of AA6082 die forgings made from extruded rods. In: 5th Int. Conference "Aluminium 2007", 10. - 12. 10. 2007, Staré Splavy, Czech Republic.

[10] OČENÁŠEK, V. (2011). The effect of surface recrystallized layers on properties of extrusions and forgings from high strength aluminium alloys. In: METAL 2011, 18. - 20. 5. 2011, Brno, Czech Republic. 